14. Plugina, Iu. A. (2010). Upravlenie razvitiem kak optimalnaia model upravleniia predpriiatiem. Vestnik ekonomiki transporta i promyshlennosti, 30, 89-93.

Kulbovskyi Ivan, PhD, Associate Professor, Department of Automation and Computer-Integrated Technologies of Transport, State University of Infrastructure and Technologies, Kyiv, Ukraine, ORCID: http:// orcid.org/0000-0002-5329-3842, e-mail: kulbovskiy@ukr.net

Holub Halyna, PhD, Associate Professor, Department of Automation and Computer-Integrated Technologies of Transport, State University of Infrastructure and Technologies, Kyiv, Ukraine, ORCID: http:// orcid.org/0000-0002-4028-1025, e-mail: golub.galina@ukr.net
Skliarenko Inna, PhD, Associate Professor, Senior Researcher, Research Sector, State University of Infrastructure and Technologies, Kyiv, Ukraine, ORCID: https://orcid.org/0000-0002-1428-1793, e-mail: innakdavt@ukr.net

Bambura Olga, PhD, Department of Theoretical and Applied Mechanics, State University of Infrastructure and Technologies, Kyiv, Ukraine, ORCID: https://orcid.org/0000-0002-8602-5086, e-mail: Bambura_olja@ukr.net

Soloviova Olena, PhD, Department of Theoretical and Applied Mechanics, State University of Infrastructure and Technologies, Kyiv, Ukraine, ORCID: https://orcid.org/0000-0002-3005-3408, e-mail: alena konoplya@bigmir.net

Tokar M.

\title{
DEVELOPMENT OF A DIFFERENTIAL BLOCK CODING METHOD FOR APPLICATION IN MOBILE RADIO COMMUNICATION SYSTEMS USING MIMO SYSTEMS
}

Об'єктом дослідження даної роботи є методи і алгоритми просторово-часового блокового кодування, використовувані також в системах багатоантеного радіозв'язку (Multiple Input Multiple Output - MIMO). Реалізація систем МІМО когерентного прийому або попереднього кодування даних має на увазі знання інформацї̈ про стан каналу зв'язку i, відповідно, компенсацію його впливу. Для оцінки каналу спільно з інформаційними сигналами передаються пілот-сигнали, заздалегідь відомі на приймальній стороні. Періодичність відправки чих сигналів залежить від чинників, що змінюють стан каналу зв'язку, наприклад, один з яких - висока швидкість переміщення мобільних станцій. Але так як пілот-сигнали не несуть інформації користувачів, відбувається споживання ресурсу системи, що перешкоджає ефективному використанню радіочастотного спектру.

В ході проведення дослідження було розглянуто спосіб, що допускає відсутність необхідності знання інформацї̈ про стан каналу зв'язку - відносна фазова модулячія, який був узятий за основу і поширений для використання в системах МІМО. Даний спосіб передбачає некогерентний прийом, але, незважаючи на ще, його застосування в повній мірі виправдовується, виходячи з отриманих результатів дослідження. Також були розроблені і інтегровані в систему ефективне деревоподібне кодування і алгоритм компенсації шумових складових сигналу. Це, відповідно, дозволило оптимізувати обчислювальні потужності реалізації системи і наблизити по ефективності пропонований метод диференціального просторово-часового блокового кодування (ДПВБК) до методів когерентного прийому.

Застосовуючи пакет програм МАТLАВ, виконано моделювання запропонованого методу ДПВБК для різних варіантів кількості передавальних і приймальних антен і видів модуляції. Проведено порівняння та визначено переваги методу ДПВБК. Викладений метод може знайти застосування в сучасних системах радіозв'язку з мінливими параметрами каналу зв'язку через високу швидкість переміщення мобільних станцій.

Ключові слова: відносна фазова модуляиія, комплексна ортогональна форма, когерентний прийом, просторово-часове кодування, система МІМО, деревоподібне кодування.

\section{Introduction}

When implementing coherent reception or precoding in multi-antenna multiple communication (Multiple Input Multiple Output - MIMO) systems [1-3], it is neces- sary to know the system of information about the state of the communication channel in order to compensate it. For channel estimation, together with information signals, pilot signals known at the receiving side are transmitted. The transmission of pilot signals consumes the resource of 
the system and thus hinders the efficient use of the radio frequency spectrum $[4,5]$. Currently, work is underway to overcome this problem, to the resolution of which a significant contribution has been made [6-8].

If it is possible to pay attention to the Differential phase shift keying (DPSK) [9-11], then when using it, useful information is contained in the phase difference of two sequentially transmitted signals. The receiver selects useful information by comparing the phases of two adjacent received signals, which eliminates the need for the receiver to have information about the state of the communication channel. The condition to which the communication channel must meet is insignificant changes in the state of the communication channel in the transmission interval of two adjacent signals or signal matrices during space-time coding (STC). Failure to comply with this condition when transmitting one signal (signal matrix) will lead to erroneous detection of no more than two transmitted signals (signal matrices) and will not cause errors to multiply [12, 13]. The given specificity of DPSK allows its application in conditions of fast fading and with high mobility of movement of stations.

Based on the above, the development and study of transmission schemes that do not require the receiver and/or transmitter to know information about the state of the communication channel, which is the aim of this work, is relevant today. Thus, the object of research is the methods and algorithms of space-time block coding, also used in MIMO systems.

\section{Methods of research}

A MIMO system with $M$ transmitting and $N$ receiving antennas can be represented in the following general form (Fig. 1).

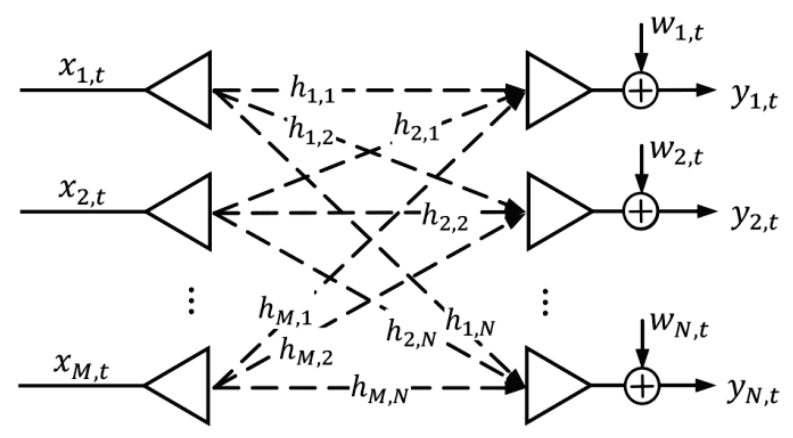

Fig. 1. Block diagram of a multi-antenna radio communication system (MIMO)

At time $t$, antenna $n$ receives a signal:

$$
y_{n, t}=\sum_{m=1}^{M} h_{m, n} x_{m, t}+w_{n, t} \text { at } n=1, \ldots, N
$$

where $h_{m, n}$ - the transmission coefficients of the communication channel from the transmitting antenna $m$ to the receiving antenna $n$, which are uncorrelated complex Gaussian random variables at $h_{m, n} \sim C N(0,1) ; x_{m, t}$ the signal transmitted by the antenna $m$ at time $t ; w_{n, t}-$ complex coefficients of additive white Gaussian noise with $w_{n, t} \sim C N\left(0, \sigma^{2}\right)$ and dispersion $\sigma^{2}$.

It should be noted that the power of the transmitted signals at each moment of time is 1 :

$$
\sum_{m=1}^{M}\left|x_{m, t}\right|^{2}=1, \text { at } t=1, \ldots, T
$$

The signals transmitted by the antenna $\mathrm{m}$ can serve as signals of the constellation L-PSK:

$$
x_{k}=\frac{1}{\sqrt{M}} \exp \left(\frac{2 \pi k i}{L}+\frac{\pi i}{4}\right), \text { at } k=0,1,2, \ldots, L-1,
$$

where $k-k$-th signal of the modulation constellation; $L$ - the number of modulation constellation signals. The signal amplitude is divided by $\sqrt{M}$ in view of condition (1).

Let's use the matrix form for the analysis of the MIMO system:

$$
\mathbf{Y}_{t}=\mathbf{H}_{t} \mathbf{X}_{t}+\mathbf{W}_{t}
$$

where $t$ is the time index for the matrices; $\mathbf{Y}_{t}-$ received matrix size $N \times 1 ; \mathbf{H}_{t}$ - matrix of channel coefficients $N \times M$; $\mathbf{X}_{t}$ - the transmitted information matrix $M \times 1$, and $\mathbf{W}_{t}$ matrix of additive white Gaussian noise.

If the condition $T_{0} \gg T_{s}$ is satisfied, where $T_{0}$ is the coherence time (duration) and $T_{s}$ is the symbol duration, the matrix of channel coefficients $\mathbf{H}_{t}$ during $T_{0}$ is relatively constant. This condition was confirmed by calculation and taken as a basis.

2.1. Coding algorithm. The transmitted sequence of bits in each of the transmission periods $p$ is divided into groups of $M L$ bits $-\mathbf{c}_{p}=\left(c_{1}, c_{2}, \ldots, c_{M l}\right)$. Then, according to the state table of the encoder compiled earlier (to be presented later), based on the combinations and previous transmitted values of the signals of the constellation L-PSK $\mathbf{x}_{p-1}=\left(x_{1}, x_{2}, \ldots, x_{M}\right)_{p-1}$, the values of the differential signals $\mathbf{x}_{p}=\left(x_{M+1}, x_{M+2}, \ldots, x_{2 M}\right)_{p}$ (belong to the constellation L-PSK) are calculated according to the formula differential encoding rule:

$$
\mathbf{x}_{p}=\mathbf{r}_{p} \mathbf{X}_{p-1}^{T},
$$

where $\mathbf{r}_{p}$ - the vector of complex differential coefficients $\mathbf{r}_{p}=\left(R_{1}, R_{2}, \ldots, R_{M}\right)_{p} ; \mathbf{X}_{p-1}-$ the complex matrix composed of signals $\mathbf{x}_{p-1}=\left(x_{1}, x_{2}, \ldots, x_{M}\right)_{p-1}$ and satisfying the orthogonality condition:

$$
\mathbf{X}^{H} \mathbf{X}=\left(\sum_{m=1}^{M}\left|x_{m}\right|^{2} \mathbf{I}_{N}\right),
$$

where $\mathbf{X}^{H}$ the Hermitian conjugation of the matrix $\mathbf{X}$. In this case, the transmit diversity order will be equal to the number of transmitting antennas $M$.

Possible values of differential coefficients $R_{1}, R_{2}, \ldots, R_{i}$ form a constellation $\mathbf{R}$, and their sets $\left(R_{1}, R_{2}, \ldots, R_{M}\right)_{j}$, each of which corresponds to a combination of input bits $c_{1}, c_{2}, \ldots, c_{M l}$, form a set $\mathbf{R}_{\text {all }}$. The number of these sets is equal to the number of encoder states $J=L^{M}$, which is determined based on their possible combinations of input bits, the number of transmitting antennas $M$, and modulation positionality PSK (Fig. 2).

Thus, differential signals $\mathbf{x}_{p}=\left(x_{M+1}, x_{M+2}, \ldots, x_{2 M}\right)_{p}$ contain transmitted bit information $\mathbf{c}_{p}=\left(c_{1}, c_{2}, \ldots, c_{M l}\right)$.

Here is an example of the encoder state table for the case $M=2$, QPSK modulation, and signal values $x_{1}=0.5+0.5 j$, $x_{2}=0.5+0.5 j$ (Table 1$)$. 


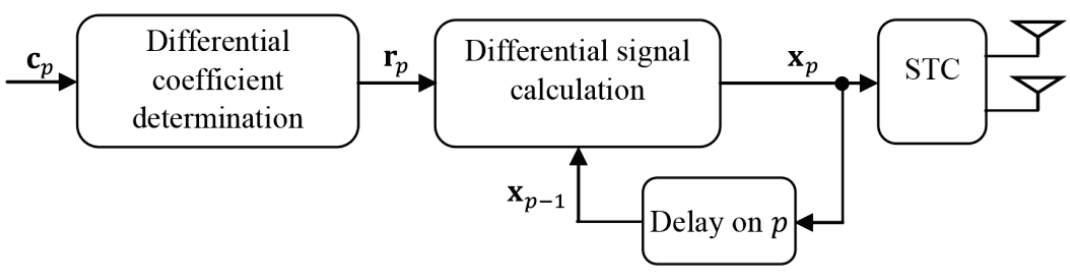

Fig. 2. The structural diagram of the encoder of differential space-time block coding (DSTBC) does not carry any information and is a reference. At time $t+2$, a block $M l$ of information bits enters the encoder, based on the values of which two differential coefficients $R_{1}$ and $R_{2}$ are determined from the encoder status table.

After that, the values of the differential signals $x_{3}$ and $x_{4}$ are calculated and:

$$
\mathbf{x}_{2}=\mathbf{r}_{2} \mathbf{X}_{1}^{T} \rightarrow\left(x_{3}, x_{4}\right)=\left(R_{1}, R_{2}\right) \mathbf{X}_{1}^{T}
$$

Table 1

Encoder state table

\begin{tabular}{|c|c|c|c|c|c|c|c|c|}
\hline$j$ & $c_{1}$ & $c_{2}$ & $c_{3}$ & $c_{4}$ & $x_{3}$ & $x_{4}$ & $A_{1}$ & $R_{2}$ \\
\hline 1 & 0 & 0 & 0 & 0 & $0.5+0.5 j$ & $0.5+0.5 j$ & 1 & 0 \\
\hline 2 & 0 & 0 & 0 & 1 & $0.5+0.5 j$ & $0.5-0.5 j$ & $0.5-0.5 j$ & $0.5-0.5 j$ \\
\hline 3 & 0 & 0 & 1 & 0 & $0.5+0.5 j$ & $-0.5+0.5 j$ & $0.5+0.5 j$ & $-0.5-0.5 j$ \\
\hline 4 & 0 & 0 & 1 & 1 & $0.5+0.5 j$ & $-0.5-0.5 j$ & 0 & $-j$ \\
\hline 5 & 0 & 1 & 0 & 0 & $0.5-0.5 j$ & $0.5+0.5 j$ & $0.5-0.5 j$ & $-0.5+0.5 j$ \\
\hline 6 & 0 & 1 & 0 & 1 & $0.5-0.5 j$ & $0.5-0.5 j$ & $-j$ & 0 \\
\hline 7 & 0 & 1 & 1 & 0 & $0.5-0.5 j$ & $-0.5+0.5 j$ & 0 & -1 \\
\hline 8 & 0 & 1 & 1 & 1 & $0.5-0.5 j$ & $-0.5-0.5 j$ & $-0.5-0.5 j$ & $-0.5-0.5 j$ \\
\hline 9 & 1 & 0 & 0 & 0 & $-0.5+0.5 j$ & $0.5+0.5 j$ & $0.5+0.5 j$ & $0.5+0.5 j$ \\
\hline 10 & 1 & 0 & 0 & 1 & $-0.5+0.5 j$ & $0.5-0.5 j$ & 0 & 1 \\
\hline 11 & 1 & 0 & 1 & 0 & $-0.5+0.5 j$ & $-0.5+0.5 j$ & $j$ & 0 \\
\hline 12 & 1 & 0 & 1 & 1 & $-0.5+0.5 j$ & $-0.5-0.5 j$ & $-0.5+0.5 j$ & $0.5-0.5 j$ \\
\hline 13 & 1 & 1 & 0 & 0 & $-0.5-0.5 j$ & $0.5+0.5 j$ & 0 & $j$ \\
\hline 14 & 1 & 1 & 0 & 1 & $-0.5-0.5 j$ & $0.5-0.5 j$ & $-0.5-0.5 j$ & $0.5+0.5 j$ \\
\hline 15 & 1 & 1 & 1 & 0 & $-0.5-0.5 j$ & $-0.5+0.5 j$ & $-0.5+0.5 j$ & $-0.5+0.5 j$ \\
\hline 16 & 1 & 1 & 1 & 1 & $-0.5-0.5 j$ & $-0.5-0.5 j$ & -1 & 0 \\
\hline
\end{tabular}

Thus, there is a one-to-one correspondence between $\mathbf{x}_{p-1}$, combination of information bits $\mathbf{c}_{p}$, differential coefficients $\mathbf{r}_{p}$ and $\mathbf{x}_{p}$. When compiling the state table of the encoder, it is possible to use the expression to find:

$$
\mathbf{r}_{p}=\mathbf{x}_{p} \mathbf{X}_{p-1}^{*}
$$

The signal matrix:

$$
\mathbf{X}_{2}=\left|\begin{array}{cc}
x_{3} & -x_{4}^{*} \\
x_{4} & x_{3}^{*}
\end{array}\right|
$$

carries information of a block $M l$ of information bits. After transmitting the matrix $\mathbf{X}_{2}$, the next block of $M l$ bits enters the encoder and the encoding then occurs according to the specified algorithm. The coding rate is 1 .

For the case $M=4$, it is possible to use the real orthogonal form [15], which involves the use of modulations of the BPSK or ASK type. Also in [15], a method for constructing real orthogonal forms for an arbitrary number of transmitting antennas with a code rate of 1 and complex orthogonal forms with a code rate of $1 / 2$ is described.

Next, let's consider the coding implementation, which is carried out according to the following tree-like algorithm (for the case $M=2$ and QPSK modulation) (Fig. 3).

Based on the fact that in this case $M l=4$ bits, encoding (determination of values $\left.\mathbf{r}_{p}=\left(R_{1}, R_{2}\right)_{p}\right)$ is carried out in four steps. The bit values $\mathbf{c}_{p}=\left(c_{1}, c_{2}, c_{3}, c_{4}\right)$ determine the path from node to node along the branches. Moving along each branch, the weights of the branches are summed. The value of the sum with an additional unit indicates the value of the state of the encoder $j$, based on which $R_{1}$ and $R_{2}$ are determined. Thus, having 4 input bits, there is no need to enumerate the encoder status table for all possible variations $(J=16)$, which optimizes the computational load and computation speed.

where $\mathbf{X}_{p-1}^{*}$ is the complex conjugation of the matrix $\mathbf{X}_{p-1}$.

Let's consider the example at $M=2$, using the complex orthogonal Alamouti form [14]. In this case, the signal transmission will be carried out according to the Table 2 .

Table 2

Signal transmission structure

\begin{tabular}{|c|c|c|c|c|}
\hline No. & $t$ & $t+1$ & $t+2$ & $t+3$ \\
\hline Antenna 1 & $x_{1}$ & $-\dot{x_{2}}$ & $x_{3}$ & $-\dot{x_{4}}$ \\
\hline Antenna 2 & $x_{2}$ & $\dot{x_{1}}$ & $x_{4}$ & $x_{3}^{\cdot}$ \\
\hline
\end{tabular}

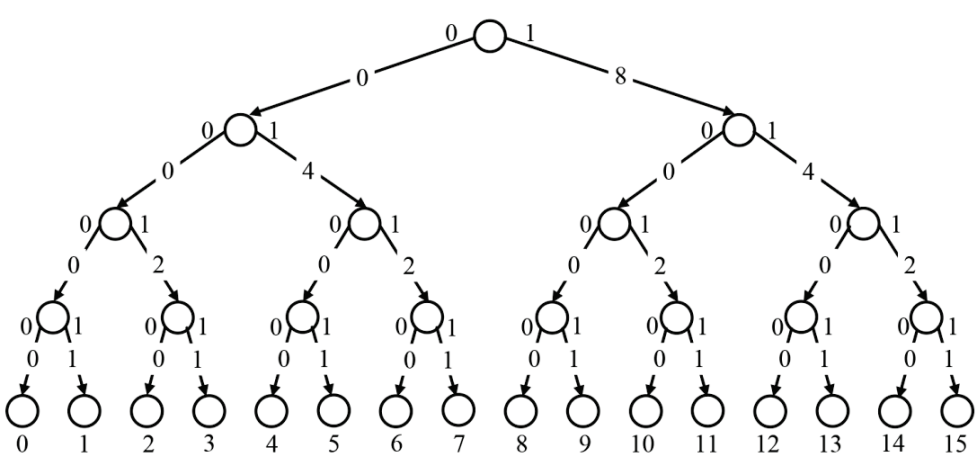

Fig. 3. Tree-like coding algorithm

The signals $x_{1}$ and $x_{2}$ can take any values $x_{k}$ of the constellation L-PSK and are transmitted respectively by the first and second antenna at time $t$, and the signals $-x_{2}^{*}$ and $x_{1}^{*}$ at time $t+1$. The matrix transmitted in this way:

$$
\mathbf{X}_{1}=\left|\begin{array}{cc}
x_{1} & -x_{2}^{*} \\
x_{2} & x_{1}^{*}
\end{array}\right|
$$

Example: If the encoder received 4 bits - 0101, then the sum of the branch weights is $0+4+0+1=5$. Adding a unit to the sum, get $j=6$ and, therefore, according to Table 1 : $R_{1}=-j, R_{2}=0$.

2.2. Decoding algorithm. As can be seen from Fig. 1 , a set of signals emitted from all transmit antennas is induced on each of the receiving antennas. It is assumed that all 
propagation channels are uncorrelated and, therefore, maximum diversity is achieved.

Let's consider the case in which $M=2$ and $N=1$. The signals received by the receiving antenna at the appropriate time points can be recorded as:

$$
\begin{aligned}
& y_{t}=h_{1} x_{1}+h_{2} x_{2}+w_{t}, \\
& y_{t+1}=-h_{1} x_{2}^{*}+h_{2} x_{1}^{*}+w_{t+1}, \\
& y_{t+2}=h_{1} x_{3}+h_{2} x_{4}+w_{t+2}, \\
& y_{t+3}=-h_{1} x_{4}^{*}+h_{2} x_{3}^{*}+w_{t+3} .
\end{aligned}
$$

In matrix form:

$$
\left|\begin{array}{c}
y_{t} \\
y_{t+1} \\
y_{t+2} \\
y_{t+3}
\end{array}\right|=\left|\begin{array}{ll}
x_{1} & x_{2} \\
x_{2}^{*} & x_{1}^{*} \\
x_{3} & x_{4} \\
x_{4}^{*} & x_{3}^{*}
\end{array}\right|\left|\begin{array}{c}
h_{1} \\
h_{2}
\end{array}\right|+\left|\begin{array}{c}
w_{t} \\
w_{t+1} \\
w_{t+2} \\
w_{t+3}
\end{array}\right| \rightarrow\left|\begin{array}{l}
\mathbf{Y}_{1} \\
\mathbf{Y}_{2}
\end{array}\right|=\left|\begin{array}{l}
\mathbf{X}_{1}^{T} \\
\mathbf{X}_{2}^{T}
\end{array}\right| \mathbf{H}+\left|\begin{array}{c}
\mathbf{W}_{1} \\
\mathbf{W}_{2}
\end{array}\right| .
$$

Then the restored values of the differential coefficients are defined as:

$$
\left|\begin{array}{l}
\hat{R}_{1} \\
\widehat{R}_{2}
\end{array}\right|=\frac{\left|\begin{array}{cc}
y_{t}^{*} & y_{t+1} \\
y_{t+1}^{*} & -y_{t}
\end{array}\right|\left|\begin{array}{c}
y_{t+2} \\
y_{t+3}
\end{array}\right|}{\left|y_{t}\right|^{2}+\left|y_{t+1}\right|^{2}} .
$$

The block diagram of the DSTBC decoder is shown in Fig. 4.

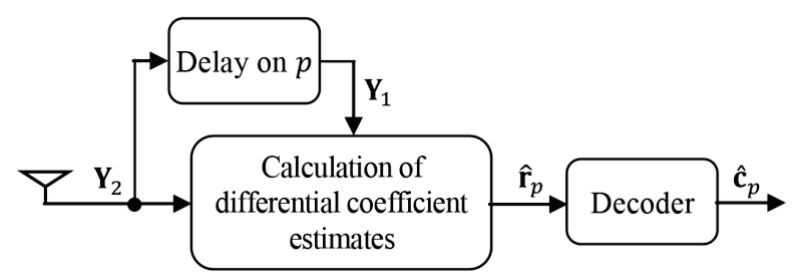

Fig. 4. The structural diagram of the differential spatial-temporal block coding (DSTBC) decoder

Further, let's agree in the notation: $y_{1}^{t}-$ the upper index determines the time instant, and the lower - the number of the receiving antenna; $\mathbf{Y}^{\langle 1\rangle}$ - the upper superscript in parentheses $\langle\cdot\rangle$ determines the column number of the matrix $\mathbf{Y}$.

At $M=2$ and $N=2$ :

$$
\begin{aligned}
\left|\begin{array}{cc}
y_{1}^{t} & y_{2}^{t} \\
y_{1}^{t+1} & y_{2}^{t+1}
\end{array}\right| & =\mathbf{X}_{1}^{T}\left|\begin{array}{ll}
h_{11} & h_{12} \\
h_{21} & h_{22}
\end{array}\right|+\left|\begin{array}{cc}
w_{1}^{t} & w_{2}^{t} \\
w_{1}^{t+1} & w_{2}^{t+1}
\end{array}\right| \rightarrow \mathbf{Y}_{1}=\mathbf{X}_{1}^{T} \mathbf{H}+\mathbf{W}_{1}, \\
\left|\begin{array}{ll}
y_{1}^{t+2} & y_{2}^{t+2} \\
y_{1}^{t+3} & y_{2}^{t+3}
\end{array}\right| & =\mathbf{X}_{2}^{T} \mathbf{H}+\left|\begin{array}{cc}
w_{1}^{t+2} & w_{2}^{t+2} \\
w_{1}^{t+3} & w_{2}^{t+3}
\end{array}\right| \rightarrow \mathbf{Y}_{2}=\mathbf{X}_{2}^{T} \mathbf{H}+\mathbf{W}_{2} .
\end{aligned}
$$

In this case, the restored values of the differential coefficients are defined as:

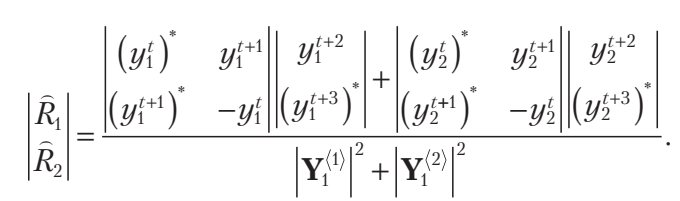

In a similar way, the values of differential coefficients are calculated for the case $M=4$.

After the reconstructed values of the differential coefficients are obtained, the receiver, by evaluating the maximum likelihood (ML), selects the closest vector $\left(R_{1}, R_{2}, \ldots, R_{M}\right)_{j}$ from the set of their combinations $\mathbf{R}_{\text {all }}$ represented by the encoder status table. After that, the transmitted sequence of bits $\widehat{\mathbf{c}}_{p}$ corresponding to the state of encoder $j$ is determined:

$$
\left(\widehat{c}_{1}, \widehat{c}_{2}, \ldots, \widehat{c}_{M l}\right)_{j}=\arg \min _{j \in \mathbf{R}_{a l l}}\left|\left(R_{1}, R_{2}, \ldots, R_{M}\right)_{j}-\left(\widehat{R}_{1}, \widehat{R}_{2}, \ldots, \widehat{R}_{M}\right)\right|^{2} .
$$

Next, let's describe an algorithm for compensating noise components. Let's draw attention to the fact that after receiving $\mathbf{Y}_{1}$, and $\mathbf{Y}_{2}$ becomes possible to estimate the values of the channel matrix (provided that the decoding $\widehat{\mathbf{c}}_{p}$ is valid and $\mathbf{X}_{1} \neq \mathbf{X}_{2}$ ):

$$
\mathbf{H}=\left(\mathbf{X}_{1}^{T}-\mathbf{X}_{2}^{T}\right)^{-1}\left(\mathbf{Y}_{1}-\mathbf{Y}_{2}\right)
$$

therefore, it is possible to restore the values of the noise matrix $\mathbf{W}_{1}$ when receiving $\mathbf{Y}_{1}$, and $\mathbf{W}_{2}$, when receiving $\mathbf{Y}_{2}$ :

$$
\begin{aligned}
& \mathbf{W}_{1}=\mathbf{Y}_{1}-\mathbf{X}_{1}^{T}\left(\mathbf{X}_{1}^{T}-\mathbf{X}_{2}^{T}\right)^{-1}\left(\mathbf{Y}_{1}-\mathbf{Y}_{2}\right), \\
& \mathbf{W}_{2}=\mathbf{Y}_{2}-\mathbf{X}_{2}^{T}\left(\mathbf{X}_{1}^{T}-\mathbf{X}_{2}^{T}\right)^{-1}\left(\mathbf{Y}_{1}-\mathbf{Y}_{2}\right) .
\end{aligned}
$$

But, since the decoding of the bits $\widehat{\mathbf{c}}_{p}$ transmitted by the matrices $\mathbf{X}_{1}$ and $\mathbf{X}_{2}$ has already occurred, it is possible, having determined the values of the noise matrix $\mathbf{W}_{2}$, subtract them from $\mathbf{Y}_{2}$ and use the obtained one (that is, the vector $\mathbf{Y}_{2}$ without taking into account the influence of noise) and the next received vector $\mathbf{Y}_{3}$ to restore the differential coefficients $\widehat{R}_{1}, \widehat{R}_{2}, \ldots, \widehat{R}_{M}$ and decode the subsequent transmitted bits $\widehat{\mathbf{c}}_{p}$. Thus, the condition - two signals (vectors) $\mathbf{Y}_{p}$ and $\mathbf{Y}_{p+1}$ are involved in decoding and, upon which interference and noise of the communication channel are superimposed - changes, and, already in this situation, when decoding, only one vector of received signals will be affected by noise, and from the second it influence will be removed. The described algorithm makes it possible to approximate the DSTBC method to the methods of coherent reception in efficiency, despite the fact that these methods use pilot signals that do not contain useful user information, thereby being redundant and do not allow efficient use of the radio frequency spectrum.

\section{Research results and discussion}

The simulation was performed in the MATLAB software package for a different number of receiving and transmitting antennas. The simulation results are presented in Fig. 5 (for $M=2$ ) as dependences of the probability of error of received symbols (BER) on the signal-to-noise ratio in the system (SNR) and are given for BPSK, QPSK, and 8-PSK modulations using Alamouti STC [14], a typical scheme of the described differential STC [16, 17] and the proposed DSTBC. The simulation was carried out using the Rayleigh fading channel, taking into account the condition for relatively constant values of channel coefficients $h_{m, n}$ during the coherence time $T_{0}$. 

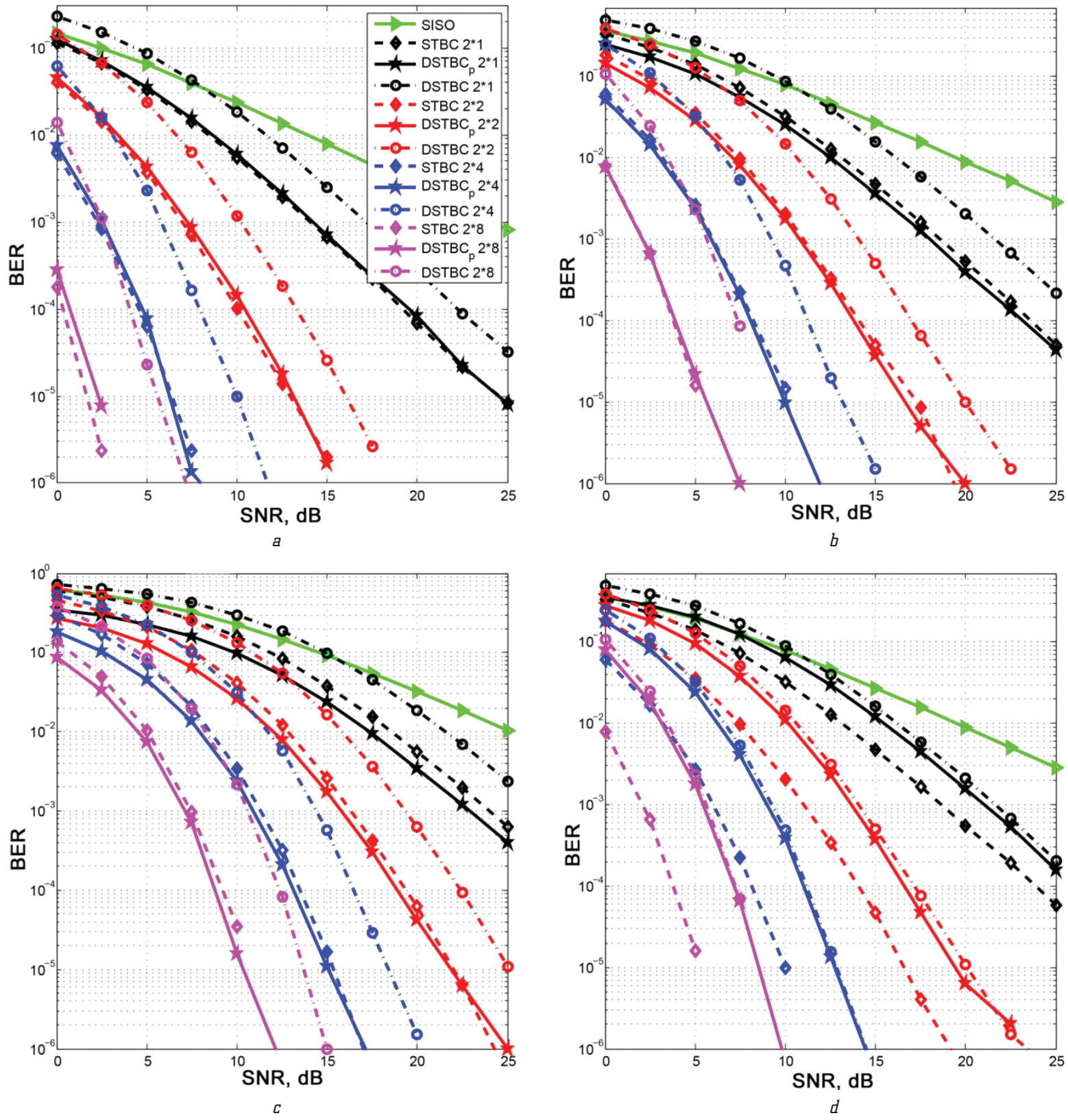

Fig. 5. Interference immunity curves for the cases under consideration:

$a$ - BPSK; $b$ - QPSK; $c$ - 8-PSK; $d$ - QPSK with the disabled noise reduction algorithm

The use of the DSTBC method for an arbitrary number of transmitting antennas is limited by the need for the availability of appropriate complex orthogonal forms. In this work, for $M=2$, the complex orthogonal Alamouti form [14] (code rate=1) is used, for $M=4$, the real and complex orthogonal forms [15] (code rate=1 and 1/2).

It should be noted that an increase in the positionality of phase modulation or the number of transmitting antennas leads to an exponential increase in the computational complexity of decoding, since the number of states of the encoding/decoding table is $J=L^{M}$. In view of this, it is advisable to use spherical decoding methods when decoding.

From the graphs in the Fig. 5 it is possible to show that in terms of efficiency with equal numbers of spatial channels of the Alamouti STC, it is almost comparable to the proposed DSTBC (when the noise compensation algorithm is turned on) and they both outperform a typical differential STC by $3 \mathrm{~dB}$ on average. This is a definite result. This can be said about comparing the noise immunity of coherent Alamouti STC and incoherent DSTBC. It should also be emphasized that the Alamouti PVC was modeled taking into account reliable knowledge of the state of the communication channel, which is not achievable in all cases. It is also possible to note that in the STC implementation, as already mentioned, channel estimation is necessary with the help of pilot signals that consume system resources and impede the efficient use of the radio frequency spectrum, while there is no such need for the DSTBC.

It should also be noted about the effectiveness of the DSTBC without the compensation algorithm for the noise components of the communication channel (noise immunity curves with the noise compensation algorithm disabled). This is due to the cumulative increase in the distance between the nearest states determined by the points of 
the signal constellation of differential coefficients $\mathbf{R}$, compared with a similar distance of the L-PSK constellation.

\section{Conclusions}

The DSTBC method proposed in the work relates to incoherent methods. It is based on the DPSK principle, which allows there to be no need for information about the state of the communication channel at the receiving side. The method also contains the developed algorithms for tree coding and compensation of the noise components of the communication channel. This, accordingly, makes it possible to optimize the computational load of the system implementation and bring the proposed differential method closer to the coherent reception methods in terms of noise immunity.

Due to obvious advantages, the described method can find application in modern radio communication systems with rapidly changing communication channel parameters due to the high speed of movement of mobile stations.

\section{References}

1. Yang, S., Hanzo, L. (2015). Fifty Years of MIMO Detection: The Road to Large-Scale MIMOs. IEEE Communications Surveys E Tutorials, 17 (4), 1941-1988. doi: http://doi.org/10.1109/ comst.2015.2475242

2. Grigorev, V. A., Khvorov, I. A., Aksenov, V. O., Schesniak, A. S. (2015). MIMO-letnoe videnie. Radiochastotnii spektr, 2, 22-27.

3. Akyildiz, I. F., Gutierrez-Estevez, D. M., Reyes, E. C. (2010) The evolution to $4 \mathrm{G}$ cellular systems: LTE-Advanced. Physical Communication, 3 (4), 217-244. doi: http://doi.org/10.1016/ j.phycom.2010.08.001

4. Marzetta, T. L. (2010). Noncooperative Cellular Wireless with Unlimited Numbers of Base Station Antennas. IEEE Transactions on Wireless Communications, 9 (11), 3590-3600. doi: http:// doi.org/10.1109/twc.2010.092810.091092

5. Zhang, J., Zhang, B., Chen, S., Mu, X., El-Hajjar, M., Hanzo, L. (2014). Pilot Contamination Elimination for Large-Scale Multiple-Antenna Aided OFDM Systems. IEEE Journal of Selected Topics in Signal Processing, 8 (5), 759-772. doi: http://doi.org/ $10.1109 /$ jstsp. 2014.2309936
6. Goriachkin, O. V. (2003). Metody slepoi obrabotki signalov i ikh prilozheniia v sistemakh radiotekhniki $i$ sviazi. Moscow: Radio i sviaz, 230.

7. Berezovskii, A. A., Goriachkin, O. V. (2017). Slepaia identifikaciia mnogomernykh signalov i ee primenenie v MIMO-sistemakh sviazi. Elektrosviaz, 11, 30-35.

8. Kreindelin, V. B., Starovoitov, M. Iu. (2017). Predskazanie parametrov radiokanala i vybor antenn na prieme $\mathrm{v}$ sistemakh MIMO, rabotaiuschikh v standarte LTE. Elektrosviaz, 12, 22-27.

9. Poborchaia, N. E., Pestriakov, A. V. (2017). Ocenka i kompensaciia iskazhenii signala $\mathrm{v}$ priemnom trakte sistem s MIMO. Elektrosviaz, 12, 42-48.

10. Skliar, B. (2003). Cifrovaia sviaz. Teoreticheskie osnovy i prakticheskoe primenenie. Moscow: Izdatelskii dom «Viliams», 1104.

11. Ziuko, A. G., Falko, A. I., Panfilov, I. P., Banket, V. L., Ivaschenko, P. V.; Ziuko, A. G. (Ed.) (1985). Pomekhoustoichivost $i$ effektionost sistem peredachi informacii. Moscow: Radio i sviaz, 272.

12. Hughes, B. L. (2000). Differential space-time modulation. IEEE Transactions on Information Theory, 46 (7), 2567-2578. doi: http://doi.org/10.1109/18.887864

13. Petrovich, N. T. (2003). Otnositelnye metody peredachi informacii. Moscow: Kniga-M, 108.

14. Goldsmit, A. (2011). Besprovodnye kommunikacii. Moscow: Tekhnosfera, 904

15. Alamouti, S. M. (1998). A simple transmit diversity technique for wireless communications. IEEE Journal on Selected Areas in Communications, 16 (8), 1451-1458. doi: http://doi.org/ $10.1109 / 49.730453$

16. Tarokh, V., Jafarkhani, H., Calderbank, A. R. (1999). Spacetime block codes from orthogonal designs. IEEE Transactions on Information Theory, 45 (5), 1456-1467. doi: http://doi.org/ 10.1109/18.771146

17. Tarokh, V., Jafarkhani, H. (2000). A differential detection scheme for transmit diversity. IEEE Journal on Selected Areas in Communications, 18 (7), 1169-1174. doi: http://doi.org/ $10.1109 / 49.857917$

Tokar Mikhail, Postgraduate Student, Department of Theory of Electrical Communications, Odessa National O. S. Popov Academy of Telecommunications, Ukraine; Senior Lecturer, Department of Quantum Radiophysics and Communication Systems, Taras Shevchenko Transnistria State University, Tiraspol, Moldova, e-mail: himmler250884@gmail.com,ORCID: https://orcid.org/00000002-1063-7940 